\title{
EKSPRESI REALTIF MRNA LMP2A VIRUS EPSTEIN BARR PADA BERBAGAI STADIUM KARSINOMA NASOFARING DI RSUD PROF. DR. MARGONO SOEKARJO
}

\author{
Tisna Sendy Pratama ${ }^{1}$, Daniel Joko $\mathrm{W}^{1}$, Hendro Pramono ${ }^{1}$ \\ ${ }^{1}$ Dekanat Fakultas Kedokteran Unsoed, Jl. Dr. Gumbreg No. 1 Mersi, Purwokerto Timur, Bayumas, Jawa Tengah \\ email: tisna.pratama@unsoed.ac.id
}

\begin{abstract}
ABSTRAK
Karsinoma nasofaring (KNF) adalah keganasan yang tersering di kepala dan Leher. Karsinogenesis KNF dipengaruhi oleh banyak faktor seperti faktor lingkungan, genetik, dan infeksi virus. Epstein Barr Virus (EBV) terbukti berperan penting dalam karsinogenesis KNF dan salah satu protein yang berperan penting adalah LMP2A. Penelitan ini mengidentifikasi hubungan antara stadium klinis KNF, klasifikasi TNM, dan ekspresi relatif mRNA LMP2A EBV. Biopsi formalin-fixed parafin-embedded (FFPE) dari jaringan tumor primer terkumpul dari 24 pasien KNF. Sampel diproses menggunakan qRT-PCR. Data di analisa dengan metode 2- Ct dan dianalisis secara statistik. Seluruh sampel mengekspresikan LMP2A. Berdasarkan analisis statistik tidak ditemukan hubungan stadium tumor dan klasifikasi TNM dengan ekspresi relatif mRNA LMP2A. Namun demikian terdapat tren penurunan Ct dengan peningkatan stadium klinis KNF.
\end{abstract}

Kata kunci: LMP2A, mRNA, Ekspresi, Progresivitas, Epstein Barr

\begin{abstract}
Nasopharyngeal Carcinoma (NPC) is the most common malignancy of the head and neck. Carcinogenesis of NPC influenced by many factors, generally an interaction between genetic, environmental factors, and virus infection. Epstein Barr Virus (EBV) proved to play an important role in carcinogenesis of NPC. LMP2A of EBV closely associated with carcinogenesis of NPC. This study identified relationship between KNF clinical stage, TNM Classification, and relative mRNA LMP2A expression. Formalin-fixed parafin-embedded (FFPE) biopsy from primary tumor were collected from 24 nasopharyngeal carcinoma patients. The samples collected underwent qRTPCR. Data were analyzed by 2- Ct methods and statistical analysis. All sampel express mRNA LMP2A. We found that LMP2A not associated with increased tumor stage and TNM classification statistically. However, there is a decreasing trend of $\mathrm{Ct}$ in accordance with the increase of clinical stage.
\end{abstract}

Keyword: LMP2A, mRNA, Expression, Progresivity, Epstein Barr 


\section{PENDAHULUAN}

Karsinoma Nasofaring menjadi kanker pada kepala dan leher yang paling sering di Indonesia., ${ }^{1,2}$ Sejumlah $86,1 \%$ penderita KNF terdiagnosis dalam stadium lanjut (stadium III dan IV). ${ }^{3,4}$ Karsinogenesis KNF dipengaruhi oleh banyak faktor seperti faktor lingkungan, genetik, dan infeksi virus.

Epstein-Barr virus (EBV) terbukti berhubungan erat dan berperan dominan dalam onkogenesis KNF di Indonesia. ${ }^{2,4}$ Ekpresi mRNA EBV berhubungan dengan transisi sel epitelial serta onkogenesis beberapa sel tubuh. ${ }^{5}$ Karsinogenesis EBV diperantarai oleh beberapa protein yang diekspresikan pada fase laten virus, antara lain: Epstein-Barr virus-encoded small RNAs (EBER), EBV nuclear antigen 1 (EBNA1), latent membrane protein 1 (LMP1), latent membrane protein $2 \mathrm{~A} / 2 \mathrm{~B}$ (LMP2A/LMP2B), Bam HI-A region rightward transcript (BART), dan BamHI A right frame 1 (BARF1). ${ }^{6,7}$

LMP2A merupakan salah satu pendekatan virus tersebut untuk dapat lolos dari respon imun hospes mempromosikan pertumbuhan sel, inhibisi apoptosis, inhibisi diferensiasi, dan berkontribusi pada transformasi sel manusia. ${ }^{8}$ LMP2A dapat menginhibisi transduksi sinyal B-cell receptor BCR dan T-cell receptor (TCR). LMP2A EBV mengandung residu tirosin yang dapat berinteraksi dengan tirosin kinase Syk dan Lyn sehingga menginhibisi jalur sinyal sel B. ${ }^{9}$ Selain itu gugus amino terminal pada LMP2A mengandung struktur yang menyediakan tempat penempelan dari tyrosine kinase Lyn, Syk, dan ubiquitin ligases Nedd4/Itchy. Hal tersebut dapat mengaktifkan jalur sinyal PI3-K/Akt, JNK/SAPK, ERK-MAPK dan $\mathrm{Wnt} / \mathrm{N}_{\mathrm{L}}$-catenin. Pengaktivan jalur tersebut dapat mempromosikan pertumbuhan sel, inhibisi apoptosis, inhibisi diferensiasi, dan berkontribusi pada transformasi sel. ${ }^{10}$

Ekspresi mRNA LMP2A dapat menjadi biomarker infeksi laten spesifik dan penting dalam progresivitas KNF. ${ }^{11}$ Sesuai dengan perannya terhadap karsinogenesis tersebut maka analisis ekspresi mRNA LMP2A penting untuk dilakukan sehingga dapat digali pemahaman yang lebih mendalam terhadap progresivitas KNF dan juga melihat potensinya sebagai biomarker progresivitas KNF.

\section{METODE}

Penelitian ini menggunakan metode observasional dengan rancangan studi cross sectional. Sampel yang digunakan adalah jaringan dalam blok parafin yang terdiagnosis karsinoma nasofaring di laboratorium patologi anatomi RSUD Prof. dr. Margono Soekardjo sepanjang tahun 2014. Variabel bebas pada penelitian ini adalah stadium kinis dan klasifikasi TNM tumor KNF, sedangkan variabel tergantung meliputi ekspresi relatif mRNA LMP2A. ${ }^{12}$

Isolasi RNA dilakukan pada 24 sampel dengan PureLink FFPE RNA isolation kit (Invitrogen) dan 
pada tahun 2017 dilakukan sintesis cDNA dengan sistem SuperScript ${ }^{\circledR}$ III First-Strand Synthesis. Hasil cDNA dikuantifikasi dengan Thermo Scientific ${ }^{\mathrm{TM}}$ DyNAmo $^{\text {TM }}$ Flash SYBR Green qPCR Kit menggunakan mesin Real Time-Polimerase Chain Reactions (qPCR) BIOER Linkgen K (software GeneLinkK FQD 48A) sehingga menghasilkan nilai cycle threshold $(\mathrm{Ct})$ baik gen target LMP2A EBV dan gen house-keeping GAPDH. Nilai ekspresi relatif mRNA LMP2A EBV dihitung berdasarkan perhitungan 2- $\mathrm{Ct}=2-[\mathrm{Ct}(\mathrm{LMP} 2 \mathrm{~A}) \quad-$ $\mathrm{Ct}(\mathrm{GAPDH}){ }^{13}$

Ekpresi relatif mRNA LMP2A dikategorikan berdasarkan nilai $\mathrm{Ct}$ sesuai penelitian sebelumnya dengan kategori ekspresi sangat tinggi 15-20, ekpresi tinggi 20-25, ekpresi sedang 25-30 dan ekpresi rendah 30-35, dan ekpresi sangat rendah atau tidak ada ekspresi $35-40 .{ }^{14,15,16}$ Progresivitas tumor KNF dianalisis dengan membandingkan ekspresi relatif mRNA LMP2A pada sistem klasifikasi TNM. Dilakukan uji one way ANOVA dengan uji alternatif Kruskal Wallis pada nilai signifikansi $<0,05$ menggunakan software SPSS v20.

\section{HASIL}

Sejumlah 24 sampel terkumpul dari laboratorium PA RSUD Prof. dr. Margono Soekarjo, Purwokerto. Diantara sampel tersebut, 6 sampel (25\%) berasal dari pasien berjenis kelamin perempuan dan 18 sampel (75\%) berasal dari pasien laki-laki. Pada rekam medis 2 sampel tidak didapatkan catatan stadium klinisnya dan 4 sampel sampel (termasuk 2 sampel yang tidak tercatat stadium klnisnya) tidak didapatkan klasifikasi TNM nya seperti yang terlihat pada tabel 1 .

Terdapat 5 sampel $(22,72 \%)$ dengan stadium klinis II, 8 sampel $(36,36 \%)$ stadium III, dan 9 sampel $(40,91 \%)$ stadium IV serta tidak didapatkan stadium klinis I. Pada klasifikasi T, sebanyak 8 sampel $(44,44 \%)$ terklasifikasi T2, 4 sampel $(22,22 \%)$ terklasifikasi T3, dan 6 sampel $(33,33 \%)$ terklasifikasi T4. Pada klasifikasi N, sejumlah 5 sampel $(27,78 \%)$ termasuk N0, 4 sampel $(22,22 \%)$ termasuk N1, 8 sampel $(44,44 \%)$ termasuk $\mathrm{N} 2$, dan 1 sampel $(5,56 \%)$ termasuk dalam N3. Seluruh sampel terklasifikasi M0. 
Tabel 1. Hasil analisis $\Delta \mathrm{Ct}, 2-\Delta \mathrm{Ct}$, klasifikasi TNM, dan stadium klinis

\begin{tabular}{|c|c|c|c|c|c|c|}
\hline $\mathbf{C t}$ & $\Delta \mathbf{C t}$ & $2^{-\Delta C t}$ & $\mathbf{T}$ & $\mathbf{N}$ & $\mathbf{M}$ & Stadium \\
\hline 29.24 & -2.43 & 0.19 & - & - & - & IV \\
\hline 30.92 & -0.75 & 0.59 & 4 & 2 & 0 & IVA \\
\hline 26.53 & -5.14 & 0.03 & - & - & - & - \\
\hline 30.68 & -0.99 & 0.50 & 2 & 1 & 0 & II \\
\hline 26.67 & -5 & 0.03 & 2 & 1 & 0 & II \\
\hline 31.12 & -0.55 & 0.68 & 2 & 0 & 0 & II \\
\hline 30.95 & -0.72 & 0.61 & - & - & - & IV C \\
\hline 26.11 & -5.56 & 0.02 & 3 & 0 & 0 & III \\
\hline 29.04 & -2.63 & 0.16 & 4 & 2 & 0 & IV A \\
\hline 28.16 & -3.51 & 0.09 & 2 & 2 & 0 & III \\
\hline 28.33 & -3.34 & 0.10 & - & - & - & - \\
\hline 31.2 & -0.47 & 0.72 & - & - & - & III \\
\hline 33.35 & 1.68 & 3.20 & 2 & 0 & 0 & II \\
\hline 29.33 & -2.34 & 0.20 & 4 & 2 & 0 & IV A \\
\hline 27.04 & -4.63 & 0.04 & 3 & 0 & 0 & III \\
\hline 28.6 & -3.07 & 0.12 & 2 & 1 & 0 & II \\
\hline 27.85 & -3.82 & 0.07 & 2 & 3 & 0 & III \\
\hline 31.02 & -0.65 & 0.64 & 3 & 0 & 0 & III \\
\hline 27.47 & -4.2 & 0.05 & 4 & 2 & 0 & IV A \\
\hline 25.62 & -6.05 & 0.02 & 4 & 1 & 0 & IV A \\
\hline 30.37 & -1.3 & 0.41 & 2 & 2 & 0 & III \\
\hline 30.26 & -1.41 & 0.38 & 4 & 2 & 0 & IV A \\
\hline 27.8 & -3.87 & 0.07 & - & - & - & IV B \\
\hline 34.71 & 3.04 & 8.22 & 3 & 2 & 0 & III \\
\hline
\end{tabular}

Seluruh kelompok mengekspresikan mRNA LMP2A dalam kategori sedang (25-30) kecuali pada rerata stadium klinis II dan klasifikasi N2 yang termasuk kategori rendah (30-35). Berdasarkan tabel 2 dapat 
dilihat terjadi penurunan rerata $\mathrm{Ct}$ yang konsisten berbanding terbalik dengan peningkatan stadium klinis dan kategori stadium. Nilai $\Delta \mathrm{Ct}$ yang lebih rendah dari kelompok memiliki rerata $\Delta \mathrm{Ct}$ yang negatif sehingga dapat ditarik kesimpulan bahwa LMP2A terekspresi lebih tinggi dari pada GADPH pada seluruh sampel.

GADPH menghasilkan $\mathrm{Ct}$ negatif $(-\mathrm{Ct})$. Seluruh

Tabel 2. Nilai Ct 24 sampel mRNA LMP2A KNF

\begin{tabular}{|c|c|c|c|c|c|}
\hline \multirow[t]{2}{*}{ Kelompok } & Sub & Rerata & Rerata & Rerata & Kategori \\
\hline & Kelompok & $\mathrm{Ct}$ Gen & $\Delta \mathrm{Ct}$ & $2^{-\Delta C t}$ & ekpresi \\
\hline Stadium & II & 30.08 & -1.59 & 0.91 & Sedang \\
\hline \multirow[t]{2}{*}{ klinis } & III & 29.56 & -2.11 & 1.28 & sedang \\
\hline & III & 28.96 & -2.71 & 0.25 & sedang \\
\hline Kategori & awal & 30.08 & -1.59 & 0.91 & rendah \\
\hline stadium & lanjut & 29.24 & $-2,43$ & 0.73 & sedang \\
\hline Klasifikasi & 2 & 29,6 & $-2,07$ & 0,64 & sedang \\
\hline \multirow[t]{2}{*}{$\mathrm{T}$} & 3 & 29,72 & $-1,95$ & 2,23 & sedang \\
\hline & 4 & 28,77 & $-2,9$ & 0,23 & sedang \\
\hline Klasifikasi & 0 & 29.73 & -1.94 & 0.92 & sedang \\
\hline \multirow[t]{3}{*}{$\mathrm{N}$} & 1 & 27.89 & -3.78 & 0.17 & sedang \\
\hline & 2 & 30.03 & -1.64 & 1.26 & rendah \\
\hline & 3 & 27.85 & -3.82 & 0.07 & sedang \\
\hline
\end{tabular}

Pada uji bivariat antara stadium klinis KNF dan ekspresi relatif mRNA LMP2A KNF didapatkan nilai $\mathrm{p}$ sebesar 0,71 sehingga dapat ditarik simpulan tidak terdapat perbedaan ekspresi relatif mRNA LMP2A antar stadium klinis KNF. Uji yang sama dilakukan secara terpisah terhadap klasifikasi T (dimensi tumor) dan klasifikasi N (keterlibatan limfonodi) dengan variabel tergantung ekspresi relatif mRNA LMP2A.
Dari uji tersebut didapatkan nilai $\mathrm{p}$ untuk klasifikasi $\mathrm{T}$ dan klasifikasi $\mathrm{N}$ berturut-turut sebesar 0,81 dan 0,53. Sehingga dapat disimpulkan bahwa tidak terdapat perbedaan ekpresi relatif mRNA LMP2A baik pada kelompok - kelompok klasifikasi T maupun klasifikasi N. 


\section{DISKUSI}

Hasil uji statistik pada ketiga variabel (stadium, dimensi tumor, dan keterlibatan limfonodi) tidak menujukkan perbedaan ekspresi relatif mRNA LMP2A virus EBV yang signifikan pada tiap kelompoknya. Sehingga dapat diambil kesimpulan bahwa ekspresi mRNA LMP2A pada sampel FFPE di penilitian ini tidak berpotensi sebagai petanda biologi molekul progresivitas tumor KNF.

Sebagian besar sampel $(77,27 \%)$ terdiagnosis pada stadium lanjut (III-IV). Walaupun KNF merupakan keganasan kepala leher paling sering di Indonesia, berdasarkan data tersebut menunjukkan terjadinya keterlambatan diagnosis. Praktisi klinis (dokter spesialis THT, dokter saraf, dan dokter gigi) dapat mengalami kesulitan untuk mendiagnosis KNF stadium awal dikarenakan kesulitan dalam pemeriksaan KNF serta fakta bahwa KNF tidak memiliki tanda atau gejala yang spesifik. $^{2}$

Tidak seperti LMP1, LMP2A ditemukan secara konsisten pada sebagian besar KNF walupun pada kadar ekspresi yang rendah. ${ }^{17}$ Hal tersebut juga serupa dengan nyang dilakukan oleh Fotheringham (2013) dkk yang mendapatkan secara konsisten LMP2A pada sel KNF. ${ }^{18}$ Beberapa penelitian sebelumnya didapatkan bukti bahwa ekspresi LMP2A memiliki hubungan yang signifikan dengan transisisi keganasan. ${ }^{19,20}$ Pada pecobaan in vitro, LMP2A selalu terdeteksi serta menimbulkan efek peningkatan migrasi, motilitas, dan inhibisi diferensiasi yang merupakan karakteristik dari perkembangan tumor. ${ }^{18}$ LMP2A dapat menginduksi epithelial-mesenchmal transition (EMT) dengan mengaktivasi metastatic tumor antigen 1 (MTA1) pada tingkat translasional melalui sinyal aktivasi mTOR dan axis 4EBP1-eIF4E. ${ }^{19}$

Beberapa studi mencoba memepelajari lebih dalam peran LMP2A seperti yang dilakukan oleh Ma dkk (2017) yang menunjukkan walaupun dengan delesi dari LMP2A (juga LMP1) tidak mencegah munculnya tumor namun hanya tertunda onsetnya. ${ }^{21} \mathrm{Hal}$ tersebut menunjukkan bahwa protein tersebut tidak cukup esensial namun berperan pada proses awal perubahan tumor.

Hasil yang tidak signifikan dapat dipengaruhi kualitas isolasi RNA. Kenaikan suhu dan integritas RNA juga menjadi faktor yang membatasi performa RT-PCR. ${ }^{22}$ Kualitas isolasi pada sampel FFPE ditentukan oleh dua faktor, yaitu kualitas sampel jaringan dan modifikasi kimia oleh formaldehid. Kualitas sampel dipengaruhi oleh waktu antara reseksi dan fiksasi, waktu penyimpanan, kondisi blok parafin, dan kondisi embedding (waktu inkubasi dan temperatur pada parafin panas). Modifikasi kimia RNA oleh formaldehid mimiliki dampak negatif yang kuat pada RT-PCR dan mungkin juga prosedur enzimatik lainnya. Dikarenakan template PCR adalah cDNA yang 
baru disintesis, efek negatif yang muncul kemungkinan disebabkan oleh inhibisi reaksi reverse transcription. ${ }^{22}$

Dengan variabilitas pengambilan dan pemrosesan jaringan, blok jaringan FFPE dapat disimpan hingga 12 tahun hingga digunakan untuk ekstraksi RNA, DNA, dan protein. ${ }^{23}$ Walaupun demikian, RNA terdegradasi dari waktu ke waktu menjadi fragmen-fragmen kecil. Semakin tua umur suatu FFPE akan semakin menurun pula kualitas dan kuantitas RNA karena terdegradasi seiring waktu. ${ }^{24}$

Fiksasi dengan formaldehid secara efisien dan ireversibel menonaktifkan RNAse endogen. Berdasarkan fakta tersebut kerusakan RNA dari sampel FFPE terrkait erat proses embedding seperti waktu antara reseksi dan onset dari fiksasi. Untuk sampel FFPE yang disimpan dalam waktu yang cukup lama (tahunanan), fragmentasi dari RNA yang terisolasi mencerminkan waktu penyimpanan, kondisi (temperatur) dan perlakuan terhadap sampel saat embedding. ${ }^{22}$

Ukuran sampel saat diproses menjadi blok parafin juga menentukan kualitas dari RNA yang berasal dari FFPE. Terlalu besarnya ukuran spesimen dapat mencegah penetrasi dari formaldehid menembus jaringan sehingga RNAse tidak. $^{22}$ Beberapa peningkatan protokol FFPE standar dapat dilakukan untuk memperbaiki kualitas sampel, seperti fiksasi pada suhu rendah atau penyimpanan vakum. ${ }^{25}$ Sampel yang ideal adalah ketebalannya tidak lebih dari $5 \mathrm{~mm}$ untuk. $^{22}$

Hasil yang tidak signifikan pada penelitian ini perlu untuk dikonfirmasi lebih lanjut dengan jumlah sampel dan sediaan sampel yang lebih baik. Kualitas sampel sangat penting dalam pemeriksaan RNA karena sifat alami dari RNA yang strukturnya yang lebih labil dibanding dengan DNA. Sifat tersebut membuat keterbatasan pada pemeriksaan mRNA sehingga memerlukan sampel dan teknik isolasi RNA yang baik.

Untuk penelitian selanjunya sebaiknya dilakukan pada skala yang lebih besar dan idealnya terdapat kelompok kontrol (biopsi jaringan nasofaring non KNF). Selain itu, untuk meningkatkan akurasi pemeriksaan akan lebih baik menggunakan sampel fresh frozen sehingga dapat memberikan gambaran ekspresi yang lebih baik.

\section{UCAPAN TERIMAKASIH}

Saya haturkan banyak terimakasih kepada Fakultas Biologi Unsoed khususnya bagian biologi molekuler atas fasilitasi tempat dan alat dalam penelitian ini. Selanjutnya saya ucapkan juga banyak terimakasih kepada Fakultas Kedokteran Unsoed khususnya bagian Patologi Anatomi yang sudah memfasilitasi pengumpulan sampel penelitian. 


\section{KELAYAKAN ETIK}

Penelitian ini telah melalui telaah etik oleh Komisi Etik

Penelitian Kesehatan Fakultas Kedokteran Unsoed

dengan No. 0549/UN23.07.5.1/2017

\section{DAFTAR PUSTAKA}

1. Wildeman MA, Fles R, Herdini C, Indrasari RS, Vincent AD, Tjokronagoro M, Stoker S, Kurnianda J, Karakullukcu B, Taroeno-Hariadi KW, Hamming-Vrieze O, Middeldorp JM, Hariwiyanto B, Haryana SM, Tan IB. 2013. Primary Treatment Results of Nasopharyngeal Carcinoma (NPC) in Yogyakarta, Indonesia. Plos One Vol 8 issue 5.

2. Adham M, Kurniawan AN, Muhtadi AI, Roezin A, Hermani B, Gondhowiardjo S, Tan IB, and Middeldorp JM. 2012. Nasopharyngeal Carcinoma in Indonesia: Epidemiology, Incidence, Signs, and Symptoms at Presentation. Chin J Cancer; 31(4): 185-196.

3. Susworo R. 2004. Kanker nasofaring : epidemiologi dan pengobatan mutahkhir. Cermin Dunia Kedokteran. 2004; 144: 16-9.

4. Brennan. 2006. Nasopharyngeal carcinoma. Orphanet J Rare Dis.; Vol. 1: 23.

5. Scholle F, Bendt KM, dan Raab-Traub N. 2000. Epstein-Barr Virus LMP2A Transforms Epithelial Cells, Menginhibisi Cell Differentiation, and Activates Akt. J. Virol. 74 (22): 10681-10689.

6. Fles R, Wilderman MA, Sulistiono B, Haryana SM, Tan IB. Knowledge of general practioners about nasopharyngeal cancer at Puskesmas in Yogyakarta, Indonesia. BMC Medical Education 2010; 10 (81).

7. Middeldorp JM, Brink AATP, van den Brule AJC, Meijer CJLM. Pathogenic roles for EpsteinBarr virus (EBV) gene products in EBVassociated proliferative disorders. Crit Rev Oncol Hematol 2003; 45 : 1-36.Scholle F, Bendt KM, dan Raab-Traub N. Epstein-Barr Virus LMP2A Transforms Epithelial Cells, Inhibits Cell Differentiation, and Activates Akt. J. Virol. 74 (22): 10681-10689.

8. Lin JH, et al. 2015. Epstein-Barr virus LMP2A suppresses MHC class II expression by regulating the B-cell transcription factors E47 and PU.1. Blood vol 125, issue 14: 2228-2238.

9. Damania B. 2004. Oncogenic -herpesviruses: Comparison of Viral Proteins Involved in Tumorigenesis. Nature Reviews Microbiology, 2: 656-668
10. Morris MA, Dawson CW, dan Young LS. 2009. Role of the Epstein-Barr virusencoded latent membrane protein-1, LMP1, in the pathogenesis of nasopharyngeal carcinoma. Future Oncology 5(6):811-25

11. Steven SJC, Verkuijlen SAWM, Hariwiyanto B, Harijadi, Paramita DK, Fachiroh J, Marlinda Adham, Tan IB, Haryana SM, Middeldorp JM. Noninvasive diganosis of nasopharyngeal carcinoma : nasopharyngeal brushing reveal high Epstein-Barr virus (EBV) DNA load and carcinoma-specific viral BARF1 mRNA. Int J Cancer. 2006; 119: 608-614.

12. Cancer American Joint Committee on (2010). Pharynx (Including Base of Tounge, Soft Palate, and Uvula)', in Stephen Edge, et al. (eds.), AJCC Cancer Staging Manual (7 edn.; New York: Springer-Verlag), 33-45.

13. Livak KJ dan Schmittgen TD. 2001. Analysis of relative gene expression data using real-time quantitative PCR and the 2(-Delta Delta C(T)) Method. Methods.;25(4):402-8.

14. Budiman F, Zoraya A, dan Nurhalim M. 2015. The Existence of mRNAs and miRNAs Expressions for Maintaining Cell Survival Networks Associated with the Human Transparent and Cataractous Lens. J. Ocular Biol. 3(1):8.

15. Shahib MN, Budiman, dan Feranty ZA. 2015. Studies on Gene Expressions at the RNA Level Associated with the Senile Lens Changes in Human Lens Cataract. Donnish J. Med. Med. Sci. 2(3):011-8.

16. Yussy AD, Chippy A and Shahib NM. 2015. The Role of Myeloid Derived Suppressor Cells and CXCR4 Genes Expression for Nasopharyngeal Carcinoma Progression. J. Sci. Res. Stud. 2(8): 195-201.

17. Bell AI, Groves K, Kelly GL, et al. 2006. Analysis of Epstein-Barr Virus Latent Gene Expression in Endemic Burkitt's Lymphoma and Nasopharyngeal Carcinoma Tumour Cells by Using Quantitative Real-Time PCR Assays. Journal of General Virology ; 87:2885-2890.

18. Julie A. Fotheringham dan Raab-Traub N. Epstein-Barr Virus Latent Membrane Protein 2 Effects on Epithelial Acinus Development Reveal Distinct Requirements for the PY and YEEA motifs. J. Virol. December 2013 vol. 87 no. 24 13803-13815.

19. Lin Z, Wan X, Jiang R, et al. 2014. Epstein-Barr Virus-Encoded Latent Membrane Protein 2A Promotes the Epithelial-Mesenchymal Transition in Nasopharyngeal Carcinoma via Metastatic Tumor Antigen 1 and Mechanistic Target of Rapamycin Signaling Induction. J Virol. ; 88(20): 11872- 11885. 
20. Kong QL, Hu LJ, Cao JY, Huang YJ, Xu LH, Liang Y, Xiong D, Guan S, Guo BH, Mai HQ, Chen QY, Zhang X, Li MZ, Shao JY, Qian CN, Xia YF, Song LB, Zeng YX, Zeng MS. EpsteinBarr virus-encoded LMP2A induces an epithelialmesenchymal transition and increases the number of side population stem-like cancer cells in nasopharyngeal carcinoma. PLoS Pathog.; 6(6):e1000940.

21. Ma SD, Tsai MH, Romero-Masters JC, Ranheim EA, Huebner SM, Bristol JA, Delecluse HJ, Kenney SC. Latent Membrane Protein 1 (LMP1) and LMP2A Collaborate To Promote EpsteinBarr Virus-Induced B Cell Lymphomas in a Cord Blood-Humanized Mouse Model but Are Not Essential. J Virol. 2017 Mar 13;91(7). pii: e01928-16. doi: 10.1128/JVI.01928-16.

22. von Ahlfen S, Missel A, Bendrat K, dan Schlumpberger M. 2007. Determinants of RNA Quality from FFPE Samples. PLoS ONE 2(12): e1261.

23. Chung JY, Braunschweig T, Williams R, Guerrero N, Hoffmann KM, Kwon M, Song YK, Libutti SK, Hewitt SM. 2008. Factors in tissue handling and processing that impact RNA obtained from formalin-fixed, paraffin-embedded tissue. J Histochem Cytochem. 2008 Nov; 56(11):1033-42.

24. Kokkat TJ, Patel MS, McGarvey D, LiVolsi VA, dan Baloch ZW. 2013. Archived Formalin-Fixed Paraffin-Embedded (FFPE) Blocks: A Valuable Underexploited Resource for Extraction of DNA, RNA, and Protein. Biopreserv Biobank. 11(2): 101-106.

25. Bussolati G, Annaratone L, Medico E, D'Armento G, Sapino A. 2011. Formalin fixation at low temperature better preserves nucleic acid integrity. PLoS ONE 6: e21043 doi:10.1371/journal.pone.0021043. 